\title{
New records and updated distribution map of Gastrotheca albolineata (Lutz and Lutz, 1939) (Amphibia: Anura: Hemiphractidae)
}

\author{
Rafael Cunha Pontes*, Roberta Azeredo Murta-Fonseca, Ana Carolina Calijorne Lourenço, Daniel \\ Bastos Maciel, Angele dos Reis Martins and Luciana de Oliveira Ramos
}

Universidade Federal do Rio de Janeiro, Museu Nacional, Departamento de Vertebrados. Quinta da Boa Vista, s/nº , São Cristóvão. CEP $20940-040$. Rio de Janeiro, RJ, Brazil.

* Corresponding author. E-mail: rafaelcunhapontes@hotmail.com

\begin{abstract}
Herein we present a geographical distribution map of Gastrotheca albolineata, an endemic species of marsupial treefrogs from ombrophilous formations in the Atlantic Forest biome. The new records were provided from field observations, collected specimens and data from museum specimens. The present study report new records from Rio de Janeiro state, provide an updated distribution map, and comments on its ecological aspects, thus contributing to future studies concerning the biogeography and biology of this group. Considering the lack of studies on the biology of this species as well as the lack of knowledge on its population trends, we also suggest changes in the status of conservation of the species by the IUCN.
\end{abstract}

The marsupial treefrog genus Gastrotheca Fitzinger, 1843 is composed by 58 species (Juncá and Nunes 2008; Frost 2011) and is especially diverse in Costa Rica, Panama and northern of South America. Seven species of this genus occur in eastern and southeastern Brazilian Atlantic Forest (Duellman 1984; Caramaschi and Rodrigues 2007), including Gastrotheca albolineata, a medium-sized treefrog described from Serra dos Órgãos mountain range in Rio de Janeiro state, Brazil. Its distribution area was recently extended to the municipality of Ubatuba (distant $250 \mathrm{~km}$ from type-locality), northern coast of São Paulo state (Gressler et al. 2008), municipality of Mangaratiba (distant $150 \mathrm{~km}$ from type-locality) (Carvalho-e-Silva et al. 2008) and municipality of Nova Friburgo (distant $50 \mathrm{~km}$ from type-locality) (Siqueira et al. 2011), both in Rio de Janeiro state, and to the municipality of Santa Teresa, state of Espírito Santo (Almeida et al., 2011), Brazil.

Despite the incipient knowledge on its biology, distribution and scarce representativeness in scientific collections, the species is categorized as "Least Concern" by the International Union for the Conservation of Nature (IUCN) Red List for Threatened Species (Carvalho-eSilva and Telles 2004). In the last years, the systematics and taxonomy of this species was assessed by several authors (Sachsse et al. 1999; Caramaschi and Rodrigues 2007; Izecksohn and Carvalho-e-Silva 2008), but none of these studies reported an updated distribution map for $G$. albolineata. Herein we present new geographical records for $G$. albolineata in the state of Rio de Janeiro and also provide an updated distribution map of the species.

We present data based on field observations from Serra da Bocaina, municipality of Paraty, two specimens collected in the district of Sampaio Corrêa, municipality of Saquarema - both localities in the state of Rio de Janeiro, and specimens housed at Coleção de Anfíbios of Museu Nacional / Universidade Federal do Rio de Janeiro (MNRJ).
License for scientific activity was issued by Sistema de Autorização e Informação em Biodiversidade, SISBIO; Instituto Brasileiro do Meio Ambiente e dos Recursos Naturais Renováveis, IBAMA (no 21619-1).

On August 1, 2011, a survey of the anurofauna of the Parque Nacional da Serra da Bocaina, municipality of Paraty (2312'28.11" S, 4448'21.36" W; 384 m above sea level; SAD 69), southeastern Brazil was conducted. This protected area corresponds to a large fragment (104.000 ha) covered by ombrophilous submontane and montane forest (IBAMA 2011). During a rainy night $\left(16^{\circ} \mathrm{C}\right.$ and $89 \%$ of relative humidity) field observations were made on several specimens of $G$. albolineata vocalizing perched on trees and inside bromeliads up to $3 \mathrm{~m}$ high, near streams, from 18:00 h to 22:00 h. However, no specimens were collected.

During a fieldwork at Sampaio Corrêa district, (2252'04.0" S, 42³9'05.2" W; 233 m above sea level; SAD 69), municipality of Saquarema , state of Rio de Janeiro, southeastern Brazil, on August 10, 2011, two adult male specimens of $G$. albolineata were collected, MNRJ 75917 $(\mathrm{SVL}=45.35 \mathrm{~mm})$ and MNRJ $75915(\mathrm{SVL}=55.62 \mathrm{~mm})$ (Figure 1). The vegetation in this region is composed by lowland ombrophilous forest (Veloso et al. 1991) and corresponds to a large forested fragment in Serra do Mato Grosso, near the boundaries of the municipalities of Maricá and Saquarema. Due to the removal of native vegetation for sprawl and banana monoculture in the last decades, most of the area presents secondary formations with canopies up to $10 \mathrm{~m}$ high. Creeks and streams are also common in the interior of the forested fragments. Also during a rainy night, $\left(18.2^{\circ} \mathrm{C}\right.$ and $90 \%$ of relative humidity), both specimens were found perched and vocalizing on trees up to $3 \mathrm{~m}$ high near creeks. On the same night seven other specimens of $G$. albolineata were observed vocalizing from 16:00 h to $00: 00 \mathrm{~h}$. 
Additionally, our analysis of museum specimens revealed that $G$. albolineata also occurs in the municipality of Cachoeiras de Macacu (22²4'27” S, 4244'14" W; 306 m above sea level; SAD 69), at Serra dos Órgãos mountain range, Rio de Janeiro state (MNRJ 59537, SVL: $50.62 \mathrm{~mm}$, male; MNRJ 65496, SVL: $44.91 \mathrm{~mm}$, male; MNRJ 54401, SVL: $60.12 \mathrm{~mm}$, female containing 19 eggs).

All previous records for $G$. albolineata were closely associated to mountain ranges (Serra do Mar and Serra da Mantiqueira). Notwithstanding, the record from Saquarema municipality represents the only locality outside of these mountain range and the nearest coastline record in the state of Rio de Janeiro (ca. $6.5 \mathrm{~km}$ ) for $G$. albolineata. Considering these compilation of records, G. albolineata is currently distributed on the northern portion of Serra da Mantiqueira mountain range, hills on the coastal lowlands of Rio de Janeiro state, Serra do Mar mountain range, southern portion of Serra da Mantiqueira mountain range and northern coast of São Paulo state (Figure 2).

However, there is a gap in the species distribution along the northern of Rio de Janeiro state and southern of Espírito Santo state (ca. $300 \mathrm{~km}$ ). This gap probably occurs due to the lack of long-term studies on amphibian community along these areas (e.g. Desengano mountain range). Considering that, increasing sample efforts in those remnants may reveal the presence of $G$. albolineata
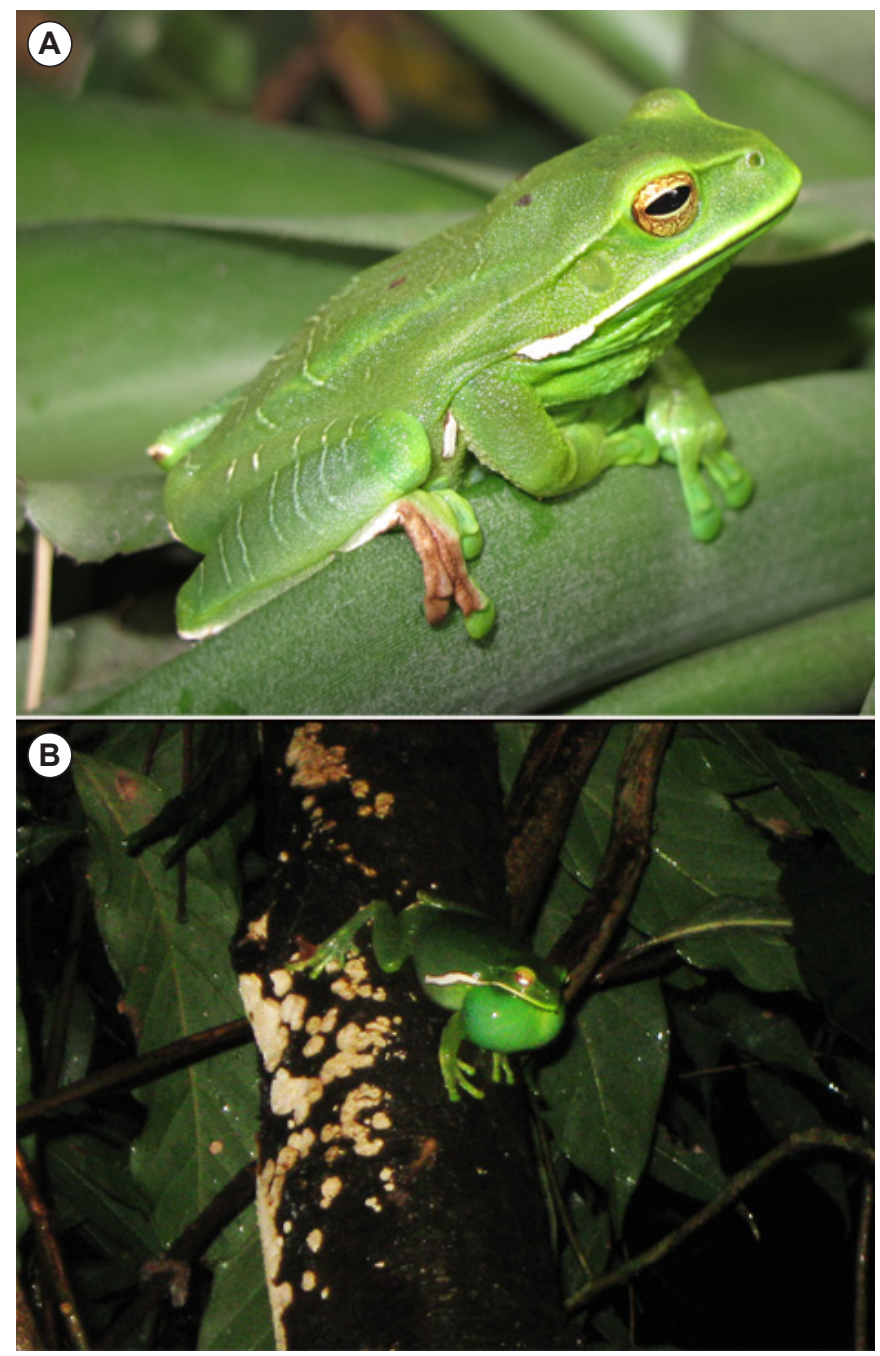

FIGURE 1. Gastrotheca albolineata, MNRJ 75915. Photos by Ivan Nunes (A) and Daniel Bastos Maciel (B). in these areas.

Most studies on $G$. albolineata were focused on its taxonomy and systematics (e.g. Caramaschi and Rodrigues 2007; Izecksohn and Carvalho-e-Silva 2008) and data on its biology and reproduction are scarce, probably due to their arboreal habits (Carvalho-e-Silva and Telles 2004). The conservation status of this species has changed since its first statement in IUCN Red List of Threatened Species. Initially, it was signaled as "Insufficiently Known" by Groombridge (1993) and was later considered as "Data Deficient" by Baillie and Groombridge (1996). In 2004, Carvalho-e-Silva and Telles listed G. albolineata as "Least Concern" in view of its wide distribution and its presumably large population, and also because these authors did not believe that the species is declining fast enough to be qualified in a more threatened category. However, considering the lack of studies on the biology of this species as well as a lack of knowledge about its population size, we provisionally suggest here the category "Data Deficient" for G. albolineata, until new studies are conducted assessing these aspects on a longterm panorama.

The present records might contribute to future studies on the biogeography of this group. Preliminary data on biology presented here could also contribute to specific studies on aspects of the ecology and reproduction of this species. Despite these new records, G. albolineata can still be considered an endemic species of ombrophilous formations in Atlantic Forest biome.

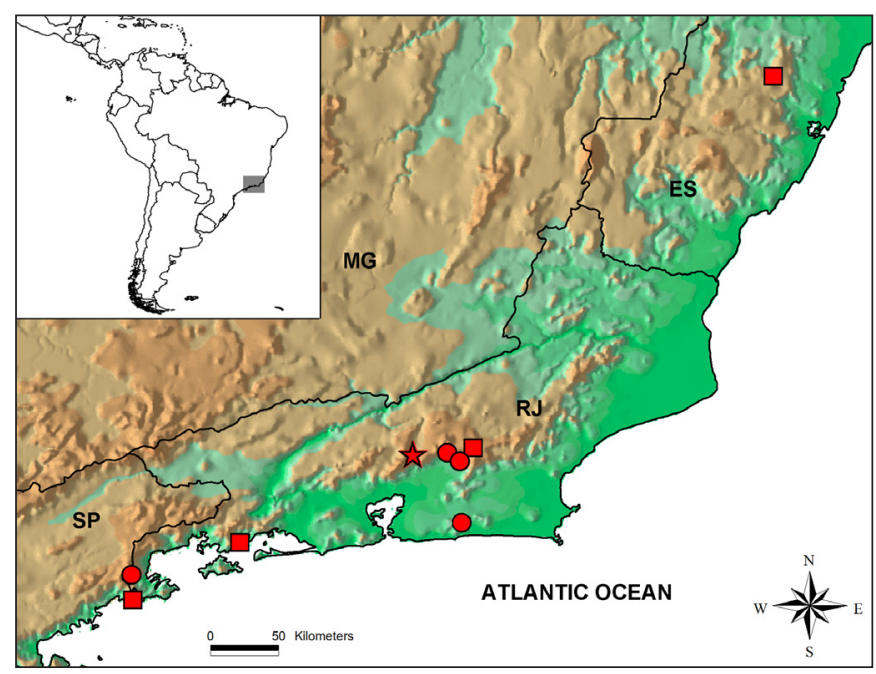

FIGURE 2. Currently distribution map of Gastrotheca albolineata. Squares: literature records; circles: records from this study; star: type-locality.

ACKNOWLEDGMENTS: We are grateful to Graça Martins and Sérgio Martins for logistical support; to Ivan Nunes for picture; and to Coordenação de Aperfeiçoamento de Pessoal de Nível Superior (CAPES) and Conselho Nacional de Desenvolvimento Científico e Tecnológico (CNPq) for financial support.

\section{Literature Cited}

Almeida, A.P., J.L. Gasparini and P.L.V. Peloso. 2011. Frogs of the state of Espírito Santo, southeastern, Brasil. The need for looking at the coldspots. Checklist 7(4): 542-560.

Baillie, J. and B. Groombridge 1996. 1996 IUCN red list of threatened animals. Gland: IUCN. 378 p.

Caramaschi, U. and M.T. Rodrigues. 2007. Taxonomic status of the species of Gastrotheca Fitzinger, 1843 (Amphibia: Anura: Amphignathodontidae) of the Atlantic Rain Forest of eastern Brazil, with description of a new species. Boletim do Museu Nacional 525: 1-20. 
Carvalho-e-Silva, A.M.T., G.R. Silva and S.P. Carvalho-e-Silva. 2008. Anuros da Reserva Rio das Pedras, Mangaratiba, RJ, Brasil. Biota Neotropica 8(1): 199-209.

Carvalho-e-Silva, S.P. and A.M.T. Carvalho-e-Silva. 2004. Gastrotheca albolineata. In IUCN 2010. IUCN Red List of Threatened Species. Version 2011.1. Electronic Database accessible at http://www. iucnredlist.org/. Captured on 24 September 2011.

Duellman, W.E. 1984. Taxonomy of Brazilian hylid frogs of the genus Gastrotheca. Journal of Herpetology 18(3): 302-312.

Frost, D.R. 2011. Amphibian Species of the World: an Online Reference. Version 5.4. Electronic Database accessible at http://research.amnh. org/herpetology/amphibia/index.php. Captured on 10 September 2011.

Gressler, E., A.G. Aguirre and C.F.D. Haddad. 2008. Amphibia, Anura, Amphignathodontidae, Gastrotheca albolineata: distribution extension, new state, and new altitudinal records. Checklist 4(1): 3132.

Groombridge B. 1993. 1994 IUCN Red List of Threatened Animals. Gland and Cambridge: IUCN. 286p.

Izecksohn, I. and S.P. Carvalho-e-Silva. 2008. As espécies de Gastrotheca Fitzinger na Serra dos Órgãos, Estado do Rio de Janeiro, Brasil (Amphibia: Anura: Amphignathodontidae). Revista Brasileira de Zoologia 25(1): 100-110.
Juncá, F.A. and I. Nunes. 2008. A new species of marsupial frogs of the genus Gastrotheca Fitzinger (Anura, Amphignathodontidae) from the state of Bahia, northeastern Brazil. Zootaxa 1907: 61-68.

IBAMA. 2011. Plano de Manejo do Parque Nacional da Serra da Bocaina. Electronic Database accessible at http://www.iucnredlist.org/. Captured on 15 September 2011.

Sachsse, R., I. Izecksohn and S.P. Carvalho-e-Silva. 1999. The systematic status of Hyla albolineata Lutz and Lutz, 1939 (Amphibia: Anura: Hylidae). Herpetologica 55(3): 401-406.

Siqueira, C.C., D. Vrcibradic, T.A. Dorigo and C.F.D. Rocha. 2011. Anurans from two high-elevation areas of Atlantic Forest in the state of Rio de Janeiro, Brazil. Zoologia 28(4): 457-464.

Veloso, H.P., A.L.R.R. Filho and J.C.A. Lima. 1991. Classificação da vegetação brasileira adaptada a um sistema universal. Rio de Janeiro: IBGE. 124p.

RECEIVED: October 2011

ACCEPTED: November 2011

PUBLISHED ONLINE: February 2012

EDITORIAL RESPONSIBILITY: Fernanda Werneck 